\title{
Human Capacity Building in Nigerian Ministries, Departments and Agencies (MDAS)
}

\author{
Article by Nebo Ogochukwu Sandra ${ }^{1}$, Ituma, Afam . $\mathrm{O}^{2} \&$ Nnamani, Desmond \\ Okechukwu $^{3}$ \\ ${ }^{1}$ Personnel Unit, Godfrey Okoye University Enugu \\ ${ }^{2}$ Dept of Business Administration \& Entrepreneurship Federal University Ndufu-Alike \\ Ikwo \\ ${ }^{3}$ Dept of Public Administration \& Local Government University of Nigeria, Nsukka \\ Email: connectogoo@yahoo.com
}

\begin{abstract}
The efficiency and effectiveness in every Ministries Departments and Agencies (MDAs) depends on the right quality of people packaged and utilized to increase output. The bureaucratic and administrative theory as propounded by "Weber" states that recruitment and selection into public organization is embedded on qualification, experience and competency as avenue for sustainable development. Undoubtedly, meritocracy has been buried on the altar of mediocrity; square peg has been paired in a round hole of plural entity. The ideology of federal character principle, quota system, and political god fatherism on the aegis of tribe, sex and religious affiliation is a bearing to secure job in Nigeria. Theoretically, it is no longer right quality human capacity recruitment; it is cognitive melodrama of manno-man syndrome is an edge to get job in Nigerian public sector whether experienced or inexperienced. The paper explores the concept, performance and challenges affecting human capacity in Nigeria and system theory were adopted as framework. The paper suggests ways to enhance improvement on human capacity in Nigeria MDAs.
\end{abstract}

Keywords: Departments, Ministries, Agencies, Utilization and Development

\section{Introduction}

Human capacity is the mixture of human and physical resources to achieve greater output; it involves the ability of employees to discharge their primary function in an organization (Lawal, 2006). Human capacity forecast the future of human components through planning, organizing, directing and controlling procurements with blueprint to acquire skills and wellmotivated workforce to achieve organizational goals (http:/www.ehow.com). It is an approach to address multi-dimension aspects of employees, ranging from enhancing technical and interpersonal skills to creative thinking (Nwachukwu, 1988). Any organizations with high input and output is sure of quality capacity as an integral part of their culture directed towards career growth focused on the present and future personnel of the organization (Cole, 2002). MDAs provide social service as separate entity is Nigeria is dated back in 1950 when the colonial masters convert railways, ports authority and Electricity Company of Nigeria to public corporations to enhance performance (Kaul, 2003). In Nigeria, MDAs compete side by side with private companies and this indicates that the private firms performed better than public organization; this has been attributed to high skilled human capacity. Some report indicates that private organizations employ the best brains and invest more on training programmes to update the knowledge of workers (Muhtar, 1997). The practice in public organization is low level commitment and this has no impact in the organizational performance. In Nigeria, public service has been relegated to second fiddle due to inadequate human capacity and manpower development. As Orewa and Adewumi (1983) states that the style of recruitment and promotion in Nigeria is anchored on the aegis of federal character principle, quota system, godfatherism, political patronage amongst others, this has inculcate redundancy and dead wood in the system. The carrot and stick approach applied to erring 
staff found wanting in their duty post is no longer in vogue; the political actors and military juntas come and go; but a civil servant is answerable to any government in power (AGIP) for survival. The public servant oils the wheel of governance, but if they fail to guide politicians towards people-oriented policy choices; the chance of sustainable development becomes dim and slim (Ubeku, 1986). It has been observed that political appointees in some MDAs use part of their budgetary allocations to compensate their kits and kinsmen. The poor motivation of staff is attributed primarily on poor funding, unskilled manpower due to politicking during recruitment, the misfits are brought in the system as unproductive employee in Nigeria bureaucracy. The paper examine factors that has been derailing MDAS in Nigeria that makes the public sector unproductive and equally proffer solutions to provide services delivery in Nigeria.

\section{Concept of capacity building}

Capacity building helps to ensure that members of the organization posses the knowledge and skills they need to perform their jobs effectively, and take on new responsibilities to adapt change conditions (Jones et al 2000). It is argued that training helps to improve quality, satisfaction, productivity, morale management succession, development and profitability (http://www.business balls.com/traindev.htm). The concept capacity refers to people, institutions that make an organization to achieve and transform goals. It involves planning, organizing, directing and controlling of man and material components; it is a blueprint to acquire well-motivated workforce operation in the enterprise to achieve organizational goals (Flippo, 1981). In human capacity building the ability to identify and analyze problems, make rational choices, proffer solutions and carry out actions designed to achieve set objectives (World Bank, 1996). The human capacity building is the planning, identifying and selecting options, executing, monitoring and evaluating implementation of plans as a supply-side of equation while capacity utilization is on demand side anchored on the overall development process (Akinola, 1997). Human capacity is the utilization of people's ability, institutions and practices within an organization or nation; this strengthens the ability for progressive change. Human capacity is embracing and this describes a distinctive approach to manage people in organizational context (Akinola, 1997, Price, 2004). Onah (2003) assert that every manager must work effectively with people and solve the management functions in the areas of organizational behavior, motivation, training, collective bargaining, labour laws, income security and personnel administration. He further states that human capacity is pivot in organizational production to enhance economic development and service delivery. The objective of human capacity is to develop the talent of workers to achieve organizational goal. Human capacity is known as personnel administration designed to enhance effectiveness in organization, it involves the use of various activities for effective management of man for the benefits of the society. The concept of human capacity indicates the nature of relationship between management and employees unions placed in the context of industrialization to shape them (Schuler, 2001 :122). Truss in McGregor (1960)assert that human capacity is anchored on the theory " $\mathrm{X}$ and $\mathrm{Y}$ ", theory " $\mathrm{X}$ " control model of management while theory "Y "integrate the need to participate and commit in organization (Truss, 1999). According to Ogunna (2007) Human capacity in MDAs is dependent on the factors of technology, motivation, resources on the optimum use of personnel, professional and technical competence of the workers. The international labour office (2000) assert that capacity building improves the prospect to find and retain a worker, output, income capacity to widen the standard of living and career choices for opportunities. Human capacity building is where an employee grew in the job through acquisition of wide experience breadth and increase confidence resulting from the exercise of valued and tested responsibilities. These enable employees reach the echelon to achieve best in his profession. This can only be achieved through performance management as Clark (2005:318) posits that the essence of performance management is to establish a framework in which performance of human capital can be directed, monitored, motivated link in the circle that can be audited (Dessler, 2008:294). 


\section{Forms of capacity building}

In any organization the capacity building takes different forms Okunola (2002), Fajana (2002) and Armstrong (2003) identified the following in governmental setting as follows:

- Pre-service training. This training is directed at providing technical-knowhow for the clientele before assumption of full employment or deployment to a new office. It is therefore a preparation process for a worker to take higher responsibility for effective service delivery.

- Induction and on-the-job training. This is aimed primarily at familiarizing newly employed workers with organizational set up, administration, policies, philosophy and methods of work. It is also concerned with the day-to-day work experiences administered through case studies/conferences, demonstration, mentoring, visits and working on actual situation.

- In-service or off-the-job-training- is organized to keep workers up to date with ideas and discoveries in the workplace or profession usually through short courses, seminars and workshops, study tours, newsletters, group exercises etc.

- Professional or graduate training- is usually organized to enhance efficiency and also to enable workers acquire higher responsibilities such as nomination of a worker with diploma certificate to acquire a university degree, Master or Doctor of Philosophy (Ph.D)Degree.

- Systematic training is the form of training that is specifically designed, planned and implemented to meet defined workers need. It is usually provided by experts who already know how to train and give meaning to specific areas of workers interest. A worker with typing skills who desire to update his competence with computer skills to cope with the new Information Communication Technology (ICT)trends is a clear example of the systematic form of training.

\section{Human capacity building in nigeria MDAs}

The performance of human capacity determines the success of the public enterprise, Baadi (1984) states that the aim of development is to change the employee behaviour on the job to improve efficiency in the sector. The contribution achieved by developing human capacity improve the performance on present job, attitude formation channeling employees' attitudes towards achievement of organizational goals, develop the operational workers and supervisors with labour turnover to checkmate absenteeism and grievance among workers, job enrichment, moral building to treat human needs. Human capacity provides present and future manpower needs of the organization by improving their skills in a specific task (Chukwuemeka, 1988). However, education increase the knowledge to understand work environment, the ability of developing employees, acquire skill in performing present task, responsibilities and authority result to increase output to improve performance on these assumptions:

- There is inadequate investment by government on human capacity in MDAs.

- Employees in MDAs are not motivated to participate in human capacity programs.

Human capacity building is the basic role of personnel management to achieve and realize organizational goals of various exogenous and endogenous variables of personnel activities; this led to the establishment of Human Resource Management in public organization (Okoli, 2000, Onyishi, 2002). The performance of human capacity to attain organizational objectives cannot be over-emphasized; Onah, (2002) and Ofoegbu (1985) amplified that a firm can mobilize all its capital inputs and still out of production, but the decision of capital mobilization is human capacity decision. The inanimate factors of production assembled in operational system are the handiwork of human act conceived by human genius realized by human efforts. The process determine goals, make investment choices, direct work effort on daily basis, maintain and service equipment fall squarely on the human capacity of an organization. It is argued that man is the main instruments for realizing organizational objectives. It is necessary to stress that in MDAs, the performance of human capacity in 
attaining goals is significant since MDAS is labor intensive organization organized and motivated to fulfill its responsibilities (Ezeani and Nwankwo, 2002). The ills of MDA must remedy human capacity problems to enhance healthy work force in Nigeria.

\section{Theoretical framework}

The theory adopted systems theory as the framework of this paper as propounded by Easton (1953), Koontz (1983), Laximikanth (2006). The theory states different part that makes up a whole, this is an assemblage of things inter-connected to form a complex unit. The system is a complex whole having parts called sub-system which is inter-related and interdependent for their functioning. It has a defined boundary to interact within environment; and the external environment is known as supra-system. It has five basic parts input, process, output, feedback and environment below.

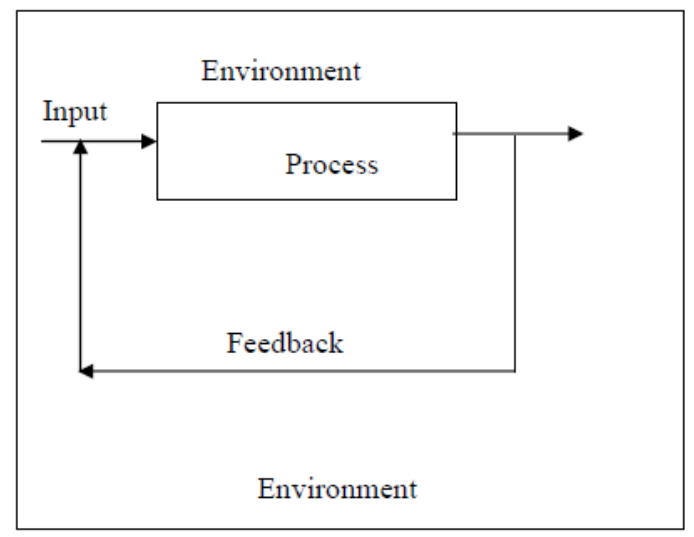

Sources: Koontz (1983).

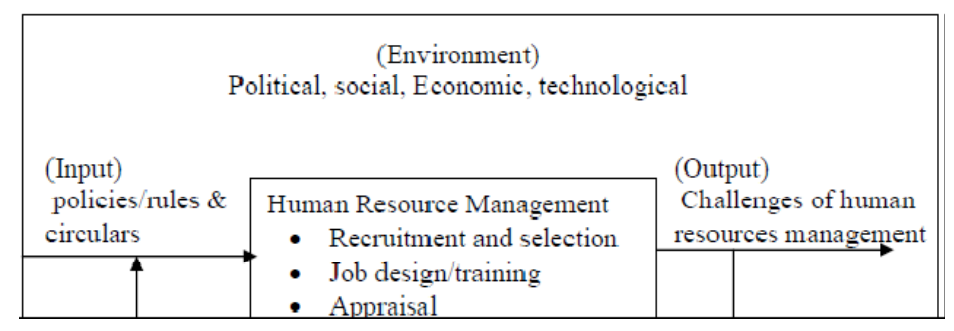

Sources: Research Data 2012

\section{Source: Easton 1953.}

The system receive input from the environment and sends output to the environment after transformation process, however the system adjusts continuously to changes in the environment. These facilitate feedback mechanism, the balance between system and its environment is cyclical (Kootnz, 1983). The output challenges bureaucrats face are indiscipline, corruption, truancy, lateness, absenteeism, embezzlement, idleness, poor remuneration, low output, workforce diversity, and mediocrity serves as feedback with time on different trends.

The Challenges of Human Capacity Building in Nigeria MDAs Ogunna (2007)state factors derailing human capacity in Nigeria MDAs are:

It has been observed that human capacity may be examine from two different angles, first, as a function or responsibility of every manager or supervisor who has people under him all of whom are working towards the achievement of desired goals. As a function in an organization which is performed by particular department, the personnel department. Deriving the above extract, there are problems of the personnel departments of the local government and there problems which the staff of the local government encounter. On the basis of the latter, Ogunna (1996)referred to it as personnel problem of the MDA among 
which are low pay, lack of adequate incentives and motivation, low prestige image. Their job is not challenging to bring out the best in them, they do not enjoy equal treatment with the state civil servants etc. on the former, he summarized as low executive capacity as they have only administrative staff and lack specialist, technicians, engineers etc. Again, there is an inadequate facility for staff training even the malfeasance of favouritism in the appointment and promotion of staff. Onyishi (2002) blamed the problems of personnel department of the MDA on over centralization hence lumping seldom makes staff assessment efficient. Onah (2002) pointed that political interference from states and influence of ethnicity, favouritism and nepotism. Majority, irregular payment of staff salaries and total absence of fringe benefits and physical working conditions which are usually very poor all impacts negatively on the personnel management of the councils.

The salaries, wages and allowances paid to workers are abysmally very low, it is a worrisome situation among MDA staff and they are attributable to this scenario. A situation where politicians earn huge amount of money every month while the public servants earn meagre amount that cannot cater for the well being of their individual families. In an attempt to meet with the challenges they engage in all forms of negative actions in one form of private business or the other for survival. The low salaries paid to workers at the MDAs worsened the high rate of inflation to difficult the lives of workers. This is compounded with nonpayment of staff salaries and allowance due to zero statutory allocations from federation account (Orewa and Adewunmi, 1983).

The colonial mentality among bureaucrats has retards productivity among MDA staff, the notion that government work is not a personal work or community work is in memory of most employees. According to Obikeze (2011), this strategy is devised by some people to resist the manipulation from the colonial masters. The employees' exhibit high rate of absenteeism, lateness, truancy even when in the office could not produce much, all this attempt to frustrate the colonial masters. The casual reflection of every public institution is corruption, ineptitude, low output, embezzlement, inefficiency heading to total collapse (Obikeze 2011). However, in an attempt to improve the living conditions of the work force in Nigeria, National Minimum wage was signed into law by President Jonathan to increase the moral of worker to make them productive, yet this idea are being frustrated at all levels especially from most governors of various states that they are unable to pay the new wages to workers. In Nigeria, the quest for material wealth is an end itself; people join public service as a means to amass wealth. However, the fund set aside for provision of amenities are diverted into personal pockets, this has breeds all forms of imaginable corruption. The 3rd Media trust annual dialogue, Nuhu Ribadu, former Chairman, Economic and Financial Crime Commission (EFCC), states that the trouble with Nigeria is corruption in the public sector (Jega 2005:9). The military administration of Murtala and Obsanjo 1975 carried out unprecedented purge in public service. This ruined their moral and impact negatively on efficiency and effectiveness (Ujomu 2000). The Buhari and Idiagbon military regime made an effort to reduce the consequences purge but end up mere scratch in the surface. The civilian administration in the Fourth Republic 1999 has not done much.

Non involvement of subordinates in decision making in the administrative class of MDAs demonstrates a high degree of authoritarian. The leadership style negating the notion that if the employees were carried along to give them sense of belonging and motivate them to enhance productivity (Nnadozie, 2004). The leadership style in the Nigerian MDAS produces aloofness, alienation as people are not carried along, apathy and high degree of frustration among the staff. The public servants should concern it with means and not ends; doing things well as pre-determined, not with deciding what things to do well. But today, administrators to some degree cannot limit themselves to merely executing the policies of the executive arm well. Berkley (1981:14) puts it that the complexity of their craft forces them to create policy as well. And they cannot ignore the political system within which they operate. Since the public service imposes itself and influence other aspect of the citizenry. The debate to 
enhance productivity in public sector has gathered momentum for the past 10 years as a central theme of public administration in Nigeria.

Non-politically neutrality among professional in MDAs is rare in Nigeria (Ejiofor, 1987), the political leaders are under intense pressure to reward their supporters; few political leaders accept the premise of a neutral public service. It is logical that incoming leaders would view incumbent senior public servants as part and parcel of the regime they succeed. The incoming leaders would want to shape the ideological direction of the MDAs to ease control (Okoh, 1998). The problem between public servants and political leaders in Nigeria has been frictional resistance, ministers, commissioners with executive of the departments and agencies under their custody has difficult to reconcile their spheres of responsibility. The career officers assume superiority and self-relevance to politicians who appoint them because the politicians have poor academic background while career civil servants posses such quality. The politicians are blamed for not remedying the situation; some politicians never have chance to work with professional or make a valuable contribution on the process of nation-building (Katako, 1971:417). In Nigeria, MDA constitute a major component of the annual budget except on few occasions when there is an increment in salaries without a major downsize in civil service staff (Guardian, May 11, 2005). The present democratic administration has come to grips that all efforts to attract the most skilled employees to bureaucratic position necessitate slim in the size of MDAs. The government does not have sufficient funds to finance all the policies and programmes as promised, most social service policy in Nigeria are under-funded (New Age, June 17, 2005). It is a routine practice to measure competency in the private sector; and this is not the case in the public sector. Berkley (1981 : 305)unraveled some behind the reluctance, ranging from intangibility of the products, inability to distinguish efficiency and effectiveness, legal restriction on the public sector to lack of precise definition. Weber (1947)describes the public sector as "a legal entity operating on calculable rules, and staffed by professionals. It has uniform and non-personal methods of performing its functions. It is criticized for low productivity, due mainly to political, institutional, and sociological factors. The problems are found in large degree of public service, but there have been no concerted efforts to redress it as public and civil servants.

\section{The structure and fiscal capacity in nigeria MDAs}

Human capacity is focused on public and private sector organizations globally with special reference in Nigeria (Vansant, et al 2004). Human capacity building identifies organizational plans, number of personnel in place and personnel required in future, identify internal and external sources to draw potential for recruitment and placement, development and appraisal. Human capacity building consist of putting the right number of people, the right kind of people at the right place, doing the right things for which they are suited for the achievement or organizational goals (Muhammed, 2004, Dauda 2003). The current restructuring in federal civil service saw the need for manpower planning and utilization to realize the goals on reform agenda of the present administration. In Human Resources Management, Audit and Monitoring was newly created in office of the Head of the Civil Service of the Federation to carry out human capital and manpower service. The office audit human capacity, research and advice on manpower needs, deploy and utilize the capacity in public service (Omodia, 2005). They carryout assessment on professional competency and capabilities in public service to make recommendations on who to confirm, retain or withdraw in the service for poor output. This assessment is a requirement for human capital development aimed at establishing the quality of employees' performance and determines their career progression (Yalokwu, 2000, Nongo, 2005). The civil service is an organized federal ministry, headed by a minister appointed by the president as the political head on the aegis of one nominee each from the 36 states and Abuja in the Federal Executive Council (FEC). The President nominates and appoints minister and sent to two chambers of the national assembly for confirmation. The minister serves as the political head of every ministry; with an assistant known as minister of state (junior minister) in each ministry and permanent secretary who is a career officer. Every 
ministry is attached to various departments and agencies of government. Some MDAs is attached to office of the Presidency like INEC, EFCC, Federal Civil Service Commission; and other six units that provide services to departments in civil services like:

- Establishments \& Record Office (E\&RO)

- Career Management Office (CMO)

- Manpower Development Office (MDO)

- Management Services Office (MSO)

- Common Services Office (CSO)

- Bureau of Public Service Reforms (BPSR)

The 2008 budget for Ministries, Departments and Agencies in Nigeria

\begin{tabular}{|c|c|}
\hline MDA (Ministry, Department or Agency) & Budget (Naira) \\
\hline Agriculture \& Water Resources & $113,673,666,845$ \\
\hline Auditor-General & $2,477,435,789$ \\
\hline Code of Conduct Bureau & $1,126,777,207$ \\
\hline Commerce and Industry & $7,758,202,700$ \\
\hline Culture \& National Orientation & $11,655,900,664$ \\
\hline Defence & $151,940,617,034$ \\
\hline Education & $210,444,818,579$ \\
\hline Energy & $139,783,534,336$ \\
\hline Environment, Housing and Urban Development & $15,915,443,907$ \\
\hline Federal Capital Territory & $37,958,110,000$ \\
\hline Federal Character Commission & $2,366,945,741$ \\
\hline Federal Civil Service Commission & $925,690,890$ \\
\hline Health & $138,179,657,132$ \\
\hline Transportation & $124,444,316,123$ \\
\hline Finance & $11,777,469,168$ \\
\hline Foreign \& Intergovernmental Affairs & $40,873,686,687$ \\
\hline Independent Corrupts Practices Commission & $3,588,338,165$ \\
\hline Independent National Electoral Commission & $12,693,517,785$ \\
\hline Information \& Communications & $18,183,376,503$ \\
\hline Interior & $266,371,519,798$ \\
\hline Justice & $12,695,948,416$ \\
\hline Labour and Productivity & $6,142,634,383$ \\
\hline Mines and Steel Development & $6,592,555,334$ \\
\hline National Planning Commission & $6,400,000,000$ \\
\hline National Population Commission & $5,219,851,968$ \\
\hline National Salaries, Income and Wages Commission & $441,347,573$ \\
\hline National Sports Commission & $5,562,611,171$ \\
\hline Office of the Head of the Civil Service & $6,836,928,125$ \\
\hline Police Service Commission & $599,570,075$ \\
\hline Public Complaints Commission & $2,008,996,208$ \\
\hline Revenue mobilization allocation and fiscal commission & $2,370,007,697$ \\
\hline Science and Technology & $16,306,271,658$ \\
\hline Women Affairs & $2,288,935,104$ \\
\hline Youth Development & $45,591,142,712$ \\
\hline
\end{tabular}

\section{Human capacity building and labour relation in nigeria}

Nigeria has made concerted efforts in building workers capacity at different levels to increase efficiency. This is because, the advantages of harnessing human resource in any nation is the most critical factor in the development process (NISER, 2001). This development made Nigerian government to collaborate with different world bodies to access 
South American Journal of Management

Special Edition 2016

manpower development at the global level. The government took various steps by establishing Federal manpower board and management services and training department of Federal Civil Service to meet the training need of workers.

These departments handle matters of policy formulation in respect to human resource development in the service. The National Council on establishment coordinates measures to achieve results on human resource development (HRD). Some various institutions have been established to play vital roles in capacity building programmes in Nigeria. Bur (1992)enumerated some of these training agencies as follows:

- The external aid agencies (Bureau for external aid).

- Scholarship board.

- Universities, Polytechnic or Colleges of Education.

- Planning and Budget office in the P residency.

- Professional organizations like Institute of Chartered Accountant of Nigeria (ICAN), Association of National Accountants of Nigeria (ANAN), Nigerian Institute of Management (NIM), Nigerian Institute of Safety Professionals (NISP), and Nigerian Institute of Public Relations (NIPR).

- Public Service Institutions Like Nigeria Institute for Training and Development (NITD), Administrative Staff College of Nigeria (ASCON), Centre for Management and Development (CMD), Agriculture and Rural Management Training Institute (ARMTI), ITF, National Institute for Policy and Strategic Studies (NIPSS), Command and Staff College, Nigerian Defence Academy (NDA)etc. Management Consultants

The Federal Establishment Circular (2011)states that similar other bodies that handles training of senior and management training cadres are ASCON, NIPSS, CMD and ARMTI are concerned with the building of workers capacity in Nigeria. However, the result of various reforms in the service, matters of training is now a shared responsibility between the federal civil service commission, ministries, departments and agencies (MDAs) to build workers capacity in recent times.

\section{Conclusion and recommendation}

The human capacity building has not impact in public organization through specific, project related, organizational related and job specific in the entire organization. This relates to machine, equipment, people, institutions relevant to economic development through training, utilization and retaining of managerial, professional and technical expert in the sector.

The political office holders should stop interfering on the activities of public servants, their undue interference is breeding indiscipline that brings low productivity as politicians influence the bureaucrats; top officials employ their loyalist and supporters who are not qualified. In other words, the job of civil service is used to compensate party supporters in high places.

Public bureaucracy should use improved technology in recruitment such as e-recruitment, computer information storage and reforming other task that will reduce the challenge of low productivity as competent people will be employed, These will reduce the level of corruption to an extent because a computerize bureaucracy will be devoid of ghost workers.

The establishment of an administrative commissioner would go a long way to address cases of conflicts, corrupt practices, and unreasonable political interference, especially by some inexperienced political advisers in state and federal public service. Finally, public service should train and retrain staff for operation to strategic management for service delivery to meet the challenges of technology and globalization to improve their capacity building. 


\section{References}

[1.] Akinola, C. (1997): "The Role of Bilateral Donors in Capacity Building: The Technology experience" A workshop Paper on Capacity Building and Utilization by the Federal Ministry of Finance in Collaboration with World Bank PACT workshop Abuja, Nigeria.

[2.] Akpan, N. (1982): Public Administration in Nigeria. Ibadan: Longman Nigeria Ltd

[3.] Ani, .C(1997): Democracy and Development in Africa. Ibadan: Spectrum Books Limited.

[4.] Armstrong, M (2003): A Handbook of Human Resource Management Practice: London. Kogan Page

[5.] Baikie, A. (2002): Recurrent Issues in Nigeria Education. Zaria: Tamaza Publishing Company.

[6.] Berkley, .G (1981): The Craft of Public Administration. Boston: Allyne Beacon Inc.

[7.] Bur, A (1992): "Human Resources Development and Utilization Policy for Nigeria" in Yahaya, A and Akinyele, C (eds.) Human Resource Development and Utilization: Lagos. Spectrum Books Ltd

[8.] Chukwuemeka, E. et.al (1988): Public Administration and Development Nigerian Experience. Enugu: MaryDan Publishers.

[9.] Clark, G. (2005): "Performance Management Strategies in Salaman, Get.al (eds.), Strategic Human Resource Management Theory and Practice. London: Open University Sage.

[10.] Cole, G. (2002): Personnel and Human Resources Management. London: Continuum.

[11.] Dessler, G. (2008): Human Resource Management, New Jersey: persons Education international

[12.] Easton, D. (1953): The Political System. Calcutta: Scientific Book agency.

[13.] Ejiofor, P. (1987): Management in Nigeria. Onitsha: Africana Publishers.

[14.] Ezeani, .E. and Nwankwo, B. (2002): Human Resources Management in Nigeria (eds.) Nsukka: AP Express Publishers.

[15.] Fajana, S (2006): Human Resource Management: An Introduction: Lagos. Labofin and Company Ltd.

[16.] Federal Republic of Nigeria (2013): Federal Establishment Circulars: Lagos. Federal Government Press.

[17.] FRN (1994): “Ayida Panel Report on Civil Service” Abuja: Federal Ministry of Information.

[18.] Filippo, E. (1981): Principles of Personnel Management: New York McGraw- Hill Books.

[19.] http://www.businessballs.com/traindev.htm .

[20.] Jega, M (2005): Corruption: The Trouble with Nigeria-Discharging a Burden. Proceedings of the 3rd Media Trust Annual Dialogue. Lagos: Media Trust Ltd.

[21.] Jones, G. et. al (2000): Contemporary Management New York: McGraw Hills.

[22.] Koontz, H. (1983): Management. London: McGraw-hill international books co.

[23.] Kaul, M. (2003): "Civil Service Reform: A Common Wealth Perspective. http://www.dpmforg/bulleting-may-03/challenges-governanceguy. html.

[24.] Lawal, M. (2006): Manpower Management: Handbook for Personnel managers and Administration. Abuja: Roots Nigeria Limited.

[25.] Laxmikanth, M . (2006): Public Administration for the UPSC Civil Service Preliminary Examination. New Delhi: McGraw-Hill Publishing co. Ltd.

[26.] McGregor, D. (1960): The Human Side of Enterprise. New York: McGraw- Hill.

[27.] Muhammed, B. (2004): Introduction to Human Resources Planning in Nigeria, 2nd ed. Kaduna: $\mathrm{S} \& \mathrm{Y}$ Business and communication ventures.

[28.] Muhtar, M. (1997): “Capacity Building and Utilization tools for National Development” PACT workshop Lagos.

[29.] Muchinsky, P. (2000): Psychology Applied to Work. USA: Wadsworth Thomson.

[30.] Nnadozie, U.(2004): The State, Civil Service and Underdevelopment in Nigeria. Enugu: John kens and Willy Publishing Co. Nig. Ltd.

[31.] Nongo, S. (2005): Fundamental Management, Makurdi: Aboki Publishing Company.

[32.] Nwachukwu, G. (1988): Management Theory and Practice-Onitsha: Africana Fep Publishers.

[33.] Obikeze, .O (2011): "Prospects of Public Service" in Nwachukwu, O. (ed.) Readings on the Nigerian Public Service.

[34.] Ofoegbu, R . (1985): "Personnel Recruitment and Management" in Nwosu, H (ed.)Problems of Nigerian Administration. Enugu: Fourth Dimension Publishing Company. 
South American Journal of Management

Special Edition 2016

[35.] Ogunna, A. (2007): Basic Issues in Community Development and Local Government. Owerri: Versatile Publishers.

[36.] Okoli, J. (2000): “Organization of Personnel Functions at the Local Level”. Paper Presented at zonal Workshop on "Effective Human Resources management, 9th to 11th August.

[37.] Oku, O. (2003): "The Universal Basic Education Programme: Issues and Problems of Policy Implementation" Journal of Nigeria Language Culture. Vol. 5 (1), 32- 36.

[38.] Okunola, M (2002): A Handbook for Nigerian Social Workers: Ibadan. Daybis Nig Ltd

[39.] Omodia. S. (2003): "The Family as a vehicle for sustainable democracy in Nigeria" Journal of Family Development 1 (1) pp.83

[40.] Onah, F. (2003): Human Resources Management. Enugu: Fulladu Publisher.

[41.] Onah, F. (2006): Managing Public Programmes and projects .Nsukka: Great AP Express Publishers Ltd.

[42.] Onyishi, A. (2002): "Organization of Personnel Functions at the local level in Nigeria" in Ezeani, E. and Nwankwo, B Human Resources Management in Nigeria Local Government System in Nigeria. Nsukka; AP - Express Publishers

[43.] Ubeku, A. (1986): "Management in Nigeria" Institute of Management.

[44.] Ujomu, .P (2000): “The Economy, Resource Management and Maintenance of National Security in Nigeria: A Critique of Shagari, Babangida and Abacha Regimes" Journal of Economic History, (3), 90.

[45.] Vasant et al (2004): "The Global Human Resources Crisis" http://www.thelancent.com Weber M (1947): The Theory of Social and Economic Organization. New York: Oxford University Press.

[46.] Yalokwu, P. (2000). Management: Concept and Techniques. Lagos: Peak Publishers. 